\title{
The 'Cooperative' Mode of Dismantling Communism: From groundbreaking to ordinary
}

\section{ANTONI Z. KAMIŃSKI AND BARTŁOMIEJ KAMIŃSKI}

\section{Introduction}

Developments in Poland in January-June 1989 set the stage for the final breakdown of the Soviet hegemony in Europe, whereas the launching of the Balcerowicz stabilisation-cum-transformation program paved the way for establishing foundations for competitive markets in Poland and other postcommunist countries. Three historic events, each overshadowing the earlier one, heralded the change: 1) the decision of the Polish Communist Party in January to start round table negotiations with Solidarity, which amounted to formal recognition of the opposition by the communist government; 2) signing of the round table agreements on 5 April that outlined a series of measures to assure an orderly transition to democracy; and 3) limited free elections held on 4 June. Their combined outcome was the emergence of the first government with a non-communist prime minister in Central Europe since the communist takeovers in 1948-49.

Yet, Poland's lead in political change quickly evaporated as other post-communist countries held free elections and subsequently moved faster to dismantle vestiges of communism in both polity and economy. Twenty years after the demise of communism, Poland lags behind some of its Central European counterparts. The quality of democracy in Poland leaves much to be desired when assessed against states such as the Czech Republic, Estonia and Slovenia, hereafter referred to as the Luxembourg group (which also includes Hungary). ${ }^{1}$ In the 2000s, various international rankings of the quality of democracy rather consistently placed Poland at the bottom of the Luxembourg group as well as behind Latvia, Lithuania

1 These countries were invited at the Luxembourg EU Council meeting held in 1996 to begin accession negotiations. The invitation recognised the progress they had achieved in establishing democracy and a market economy by 1995. 
and Slovakia but still above Bulgaria and Romania. In 2009, the ranking of Poland improved to the level of Hungary - above Latvia and Slovakia - but was still below the Czech Republic and Slovenia. ${ }^{2}$ Simultaneously, Poland's initially rapid economic growth performance ceased to shine; an impressive resistance to the world economic slowdown in 2008-09 appears to be the result of the failure to fully take advantage of the unprecedented world economic boom in 2000-07 rather than the quality of its institutions and policies.

While we do not offer an unambiguous answer as to why Poland ceased to be a leader in political transition, a plausible explanation is likely to be associated with the uniqueness of Poland's mode of dismantling communism leading to a 'pacted' transition of the type described by O'Donnell and Schmitter. ${ }^{3}$ In contrast with other Central European post-communist countries, in Poland, gradualism - then justified in terms of dealing with uncertainty concerning Soviet reaction as well as in terms of buying the support of communists opposed to negotiations with Solidarity - characterised the political transition.

The arrangements that allowed the communist establishment to stay in power, combined with divisions and fratricidal struggles within Solidarity, have crowded out from the political agenda the much more important issue of designing the constitutional underpinnings for a democratic society and state. Narrow interest groups championed procedural designs that could give them an upper hand in political struggles but had no interest in a serious constitutional debate. Similarly, the pacted transition with safeguards for the communist establishment impeded the emergence of high-quality democratic institutions.

This political gradualism has contrasted rather sharply with Poland's radical approach to the dismantling of central planning and its rapid transition to an open market economy. Thus, as we show in this chapter, Poland's economic performance appears to have been superior to its political one, although it was inferior in the 2000s to most of other new 2004 EU members despite the world economic slowdown in 2008.

\section{Quality of Democracy and Institutional Design in Comparative Perspective}

Since the collapse of communism, which has highlighted the importance of institutions and political arrangements for economic growth and prosperity, the 'quality of democracy' has regularly been the subject of international surveys. We use two sets of measures to capture changes in the quality of democracy

2 See <http://www.democracyranking.org/en/ranking.htm > (viewed March 2010).

3 O'Donnell and Schmitter (1986:37-9). 
in Poland and the other four members of the Luxembourg group. The first set, based on data from the European Bank for Reconstruction and Development (EBRD), assesses the pace of building a market-based economy, while the second, derived from the World Bank's data on governance, measures the change in the quality of political institutions.

\section{Dismantling of Central Planning: The pace of moving to competitive markets}

The 'economic assessment' data, derived from the estimates reported annually by the EBRD, seek to capture changes in two types of economic reforms: economic liberalisation and the emergence of institutions supporting competitive markets. The first - also labelled the 'first-generation reform' - entails the removal of central controls over prices and the state monopoly over foreign trade, the introduction of a convertible domestic currency for current account transactions, and small-scale privatisation. The second type-labelled the 'second-generation reform' - involves government and enterprise restructuring, competition policy, banking reform and interest rate liberalisation, the creation of security markets and non-bank financial institutions, and large-scale privatisation.

Critical differences between these two types of reforms pertain to the pace and scope of changes. Technically, economic liberalisation can be implemented quickly. It reflects the extent to which direct state controls over prices, foreign trade and exchange rates have been removed and the progress of small-scale privatisation. ${ }^{4}$ The pace of removal of these controls tends to be directly correlated with the quality of democracy but inversely correlated with the incidence of corruption. ${ }^{5}$ Although without some degree of economic liberalisation no market economy can emerge, the second-generation institutional reforms consolidate the transition to a market economy. These institutional arrangements can vary, however, reflecting differences in the attained level of economic development. ${ }^{6}$ In contrast with the first-generation reforms, the sequencing of institutional reforms and especially the choice of the mode of privatisation have tended to be determined by politics rather than the other way around.

Overall, Poland has stayed the course of economic reforms and established a sophisticated market economy, although its initial lead quickly evaporated (see Table 10.1). In 1990-91, Poland scored highest in economic liberalisation and institutional maturity. The Balcerowicz program, launched in January 1990, with the stroke of a pen introduced a convertible domestic currency for current account transactions, removed government controls on prices of most tradable

4 These are captured in EBRD indicators of progress in transition (see Table 10.1).

5 See Hellman (1998) and Kamiński and Kamiński (2001).

6 Sala-I-Martin et al. (2009). 
goods, drastically reduced subsidies to state-owned enterprises and exposed them to competition from imports through the final abolition of residual state controls over foreign trade transactions and the suspension of import duties. Considering that it took 12 years after World War II for Western European countries to restore the convertibility of their domestic currencies, this was a remarkably bold program. With Poland's economic growth rebounding in 1992, other ex-communist countries were encouraged to adopt similar measures. By 1995, the year preceding the EU Council's decision to begin accession negotiations, all Luxemburg group members achieved the same liberalisation score of 76 per cent (see Table 10.1). By 2008, only Slovenia lagged behind other members of the Luxemburg group in the market liberalisation score.

Poland embarked on second-generation (institutional) reforms in 1990 with the most developed institutional base. Other Luxembourg group countries, with the exception of Slovenia, have quickly caught up and overtaken Poland in secondgeneration reforms (see Table 10.2), although the differences have been rather negligible. In terms of progress in the 2000s, Estonia, together with other 2004 new EU members - Latvia, Lithuania and Slovakia - made the largest strides in establishing competition-supporting institutions.

They also recorded the strongest growth rates in the 2000s. While in 1993-99 Poland had the highest cumulative gross domestic product (GDP) growth, she had the second-lowest increase over the 2000-08 period, with only Hungary ranked below. In terms of GDP per capita relative to the richest Organisation for Economic Cooperation and Development (OECD) countries, Poland recorded the strongest increase, of 24 per cent, amongst the Luxembourg group countries in 1993-2000. But the increase of 25 per cent in 2000-08 - albeit impressive - put Poland roughly on a par with the Czech Republic and Slovenia. It was, however, well below the spectacular increases of Estonia and other Baltic states as well as Slovakia. It appears that Poland failed to take advantage of opportunities offered by unprecedented strong growth of the world economy in 2001-07. ${ }^{7}$ While the links between institutions and economic growth performance are difficult to quantify, it is rather striking that Poland's inability to tap fully the benefits of strong growth worldwide during this period coincided with a slowdown in structural second-generation reforms and contraction in the observed quality of democracy (see below).

7 Although this might have made Poland less vulnerable to a global slowdown in 2008-09, as its GDP increased 5 per cent; the contraction in GDP in Estonia of 4 per cent in 2008 has to be assessed by its cumulative increase in 2000-07 of 66 compared with Poland's cumulative increase of 33. This increases Poland's number to 38 and lowers Estonia's to 62 . 


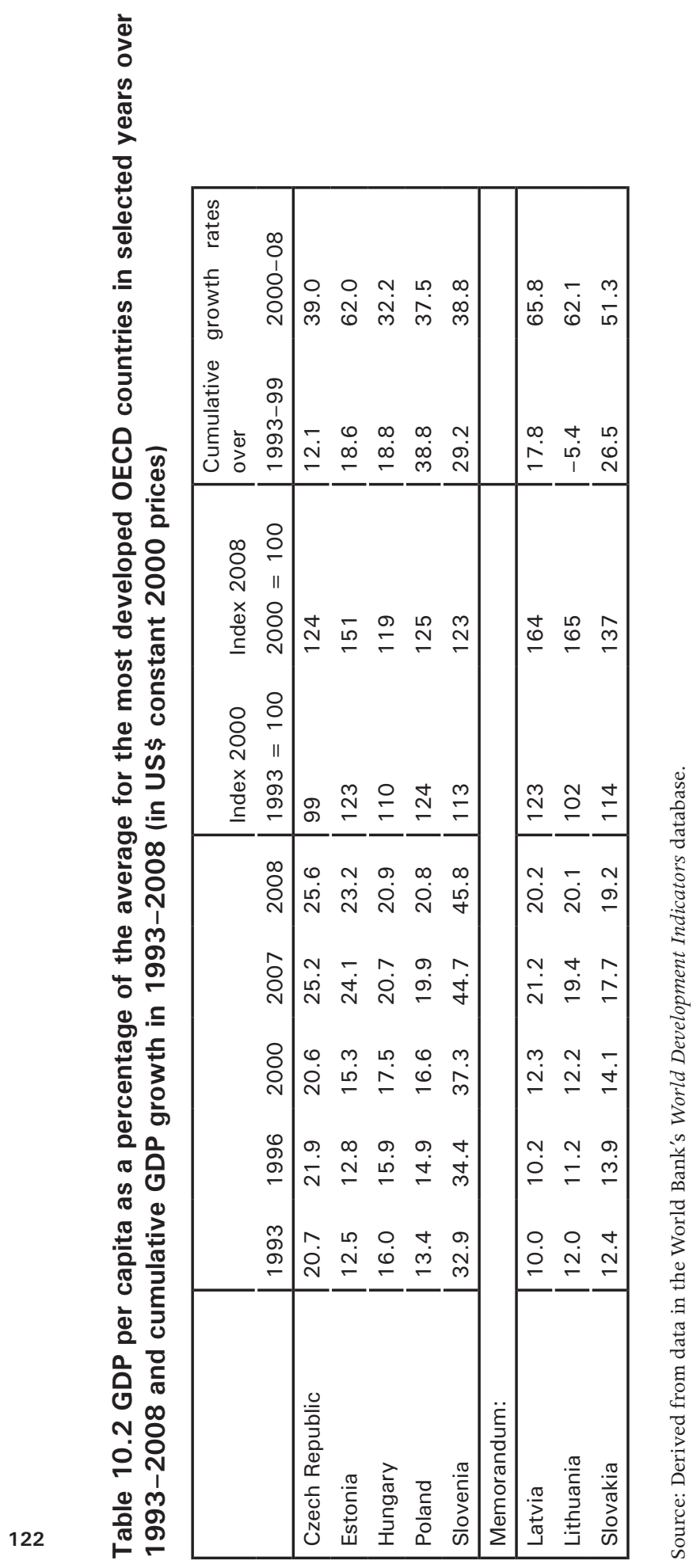




\section{The Pace of Transitioning to Liberal Democracy}

Political performance sets Poland apart from other Luxembourg group countries in one important aspect. In spite of being the only country with a huge civil society on the eve of transition - which is widely regarded to be a critical condition for high-quality democracy-it lagged behind other Luxembourg group countries over the past decade in terms of two indicators that we find useful to catch the depth of democracy and the quality of political governance: 'voice and accountability' and the 'rule of law'. These are two of seven dimensions addressed in the World Bank's annual surveys of the quality of democracy in more than 200 countries across the world. 'Voice and accountability' covers freedom of expression and its effectiveness in making the political class accountable, whereas the 'rule of law' provides assessments of the judiciary and its capacity to enforce the law. The average of percentile rankings for these two dimensions - hereafter referred to as the Quality of Democracy (QoD) indexmeasures the quality of political arrangements, with its higher values pointing to a 'better' political regime. The values of the QoD for Poland exceeded by a small margin, of 3-7 per cent, those of the worst performer in 1996-2003, and then stabilised at the bottom of the group (see Table 10.3).

Table 10.3 Change in the quality of democracy in the Luxembourg group countries and other 2004 new EU members in selected years between 1996 and 2008

\begin{tabular}{|l|llllllllll|}
\hline & 1996 & 1998 & 2000 & 2002 & 2003 & 2004 & 2005 & 2006 & 2007 & 2008 \\
\hline Czech Republic & 78 & 75 & 74 & 71 & 72 & 75 & 74 & 76 & 75 & 80 \\
Estonia & 71 & 68 & 72 & 75 & 75 & 82 & 80 & 82 & 83 & 84 \\
Hungary & 80 & 78 & 80 & 80 & 80 & 81 & 77 & 79 & 78 & 77 \\
Poland & 74 & 72 & 77 & 75 & 74 & 74 & 72 & 65 & 66 & 69 \\
Slovenia & 80 & 75 & 76 & 83 & 83 & 81 & 79 & 79 & 80 & 82 \\
\hline Memorandum: & & & & & & & & & & \\
\hline Latvia & 63 & 63 & 64 & 69 & 70 & 70 & 67 & 69 & 70 & 72 \\
Lithuania & 59 & 59 & 66 & 68 & 70 & 73 & 72 & 71 & 68 & 71 \\
Slovakia & 59 & 59 & 66 & 68 & 70 & 73 & 72 & 71 & 68 & 71 \\
\hline
\end{tabular}

Source: Authors' own calculations derived from data in Kaufmann et al. (2009).

Although Poland's political arrangements were friendlier to democracy than in two-thirds of about 250 countries surveyed by the World Bank, the decline in the QoD environment between 2000 and 2008 relative to other countries in the Luxemburg group is shown in Table 10.3. The QoD for Poland fell from 77 to 
69 per cent, with the largest contraction occurring in $2006 .{ }^{8}$ In comparison, the QoD increased between 2000 and 2008 in the Czech Republic, Estonia and Slovenia, but decreased in Hungary. This should not suggest that Poland has been moving away from democracy. Rather, other ex-communist countries have been making stronger progress. Considering the 'pro-democracy' assets that Poland seemed to have at the outset of the transition away from communism, this begs an explanation.

The most visible difference in terms of the institutional design of political governance is that Poland has opted for a mixed presidential/parliamentary system and a proportional representation (PR) electoral system. ${ }^{9}$ Amongst new EU members from Central and South-Eastern Europe, only Poland, Bulgaria and Romania have this type of government; all other countries have parliamentary democracy. In other words, the country that initiated the democratic transition from communism is the only fully fledged democracy among post-communist countries with a mixed presidential/parliamentary system. ${ }^{10}$

As all post-communist countries scoring higher than Poland on the QoD scale are parliamentary democracies, it would be tempting to conclude that the parliamentary system is better for democracy. This is not necessarily so. While Poland's QoD scores are significantly higher than those for many other countries with a mixed type of government, there are also countries with mixed parliamentary-presidential systems that achieve higher QoD scores than Poland. For example, the QoD for Poland was 10 percentage points higher in 2008 than the QoD for Bulgaria - the highest-scoring post-communist country with the mixed system of government. Among EU members, however, there are five countries - Austria, Finland, France, Ireland and Portugal — with mixed presidential and parliamentary systems that have achieved higher values of QoD than new EU members with parliamentary systems. ${ }^{11}$ Clearly, the QoD scores are not necessarily determined by the type of government system per se.

\footnotetext{
8 Furthermore, the QoD for Poland in 2008 was lower than for Latvia and Lithuania but still higher than that for Bulgaria and Romania.

9 Among Luxembourg group countries, Estonia, Lithuania and the Czech Republic have presidents elected in direct elections. Except for Lithuania, the powers of president, however, are more limited and clearly delineated, so they do not meet the criteria of a mixed type of government.

10 It is interesting to note that all Balkan countries - signatories of stabilisation and association agreements with the European Union - also have mixed systems of government. Among former Soviet republics, only Ukraine had a mixed system of government in 2008. For a comparative assessment of the quality of political environment and type of government across all post-communist countries, see Kamiński and Kamiński (2009). 11 Yesilada and Wood (2010).
} 


\section{'Pacted' Transition and Institutional Design}

Why has Poland chosen the semi-presidential type of government while other post-communist countries that experienced transition to liberal democracy without significant bumps and deviations have chosen parliamentary democracy? And, why was this arrangement-designed to guide Poland through a gradual transition to democracy before the collapse of communism in 1989-incorporated in the Constitution adopted eight years later in 1997? Also, if the choice of a semi-presidential government does not necessarily weaken democracy - as was argued earlier - what other factors related to Poland's transition from communism can explain its weaker political performance?

With regard to the choice of the type of government, the transition literature merely suggests that specific constellations of interests and expectations concerning the payoffs determine outcomes. ${ }^{12}$ Although this observation provides clues as to where to look for answers, it is fairly general and fails to account for country-specific factors associated with the collapse of communism in each ex-communist country. The uniqueness of Poland stems from the fact that it was the first country to terminate the Communist Party's monopoly of political power, thus setting an example for other Soviet Bloc countries to follow. As a pace setter, Poland-once communist and opposition leaders began their historic project of peaceful transitioning from leaky totalitarianism to democracy in January 1989- had to manage two sources of uncertainty and, thus, its departure from communism made two previous unknowns known.

First - Gorbachev's reforms notwithstanding - there was considerable uncertainty about the Soviet response to a possible loss of power by the communists. Despite Gorbachev's official rejection of the Brezhnev Doctrine in 1988, there remained considerable uncertainty about Moscow's zone of tolerance as well as about the stability of Gorbachev's position in 1989-91. Soviet apathy to Solidarity's electoral triumph signalled that Moscow recognised if not accepted the right of Soviet Bloc countries to self-determination. ${ }^{13}$

Second, since the communist establishment was not united in its desire to negotiate and possibly share power with Solidarity, the peaceful response of domestic communist authorities could not be taken for granted. Hardline local communists still hoped that Moscow's stand would change and that they could rely on their control of various levers of power. Bronisław Geremek, one of the chief personalities of the Solidarity camp, explained the lack of response

12 See, for instance, Bunce (2003:170-4) and O'Donnell and Schmitter (1986:4-7).

13 Ash (2009) quotes Rakowski's conversation in August 1989 (recorded in Rakowski's diary) with Gorbachev, who suggested that a new variant of martial law would be 'impossible... and... however wearisome it would be, we would have to get out of this situation without resorting to such means'. 
from Solidarity to frequent violations by communists in April and May 1989 of agreements reached during the round table negotiations by stressing that the communists still controlled the means of oppression and there was no certainty that they would not use them. The Solidarity side had to stick to the letter of the agreements simply because an open rebellion might have led not only to bloodshed but also to the communists' refutation of the agreements. ${ }^{14}$ On the communist side, General Jaruzelski together with his Prime Minister, Mieczysław Rakowski, had a hard time prevailing over strong internal opposition to negotiations and subsequent agreements. The split within the communist establishment shaped the dynamics and content of negotiations. Peaceful acceptance by the communist establishment of the outcome of the first, limited, free elections in June 1989 decreased, if not completely removed, this source of uncertainty.

In consequence, Poland's transition had to be 'pacted' - that is, it had to contain safeguards against both domestic and external threats to the process. While the demise of communism in Hungary is also referred to as a 'pacted' or 'cooperative' transition, ${ }^{15}$ the similarity is superficial. Although in both countries negotiations between the ruling Communist Party and the opposition preceded elections, there were important differences between them. In contrast with Poland, in Hungary, no opposition group could claim representation of a large portion of society. ${ }^{16}$ Free elections were a foregone conclusion in Hungary as there were no threats of domestic or external interventions in the aftermath of Solidarity's success in Poland's 1989 elections. And, most importantly, the Hungarian 'pact' contained no institutional safeguards that would assure the continuation of the communist establishment's hold on power, as was the case with Poland's round table agreements. The Hungarian transition did not need safeguards as Poland's pact and its outcomes effectively reduced unknowns that followers had to deal with.

The decision of the Polish communist establishment to launch negotiations with Solidarity in January 1989 was primarily a response to domestic developments throughout 1988 rather than a reaction to external shocks, although Gorbachev's policy of glasnost and perestroika as well as his new foreign policy must have also played a role. The need to deal with the wave of strikes in 1988 presented the government with a dilemma of where to look for a go-between. The mediation by the Catholic Church was not sufficient. Faced with the prospect of further unrest and the radicalisation of Solidarity, the authorities turned to Lech Wałęsa and other Solidarity leaders to help contain the growing labour unrest. ${ }^{17}$ Thus,

14 See Geremek and Żakowski (1990:145).

15 McFaul (2002).

16 Stokes (1993).

17 Kamiński and Kurczewska (1994). 
Solidarity was finally recognised as the 'official opposition' — seven years after it was declared illegal on 13 December 1981. An invitation to round table talks followed. Not unlike the communist establishment, Solidarity members were also not unanimous in their support for negotiations with those responsible for the imposition of martial law in 1981.

Hence, participants in the round table negotiations faced uncertainty about not only Moscow's zone of tolerance and the strength of Gorbachev's position within the Soviet communist establishment, but also expectations of their own constituencies. Thus, both sides were uncertain about their own strength. Solidarity was uncertain about its ability to gain wider social support and the communist establishment was uncertain about the extent of its support and its capacity to control the state's apparatus of repression. Both sides had to assess their potential payoffs - that is, economic and political changes that could be negotiated. But, both sides shared a common goal: to suppress those segments of society that wished to disrupt negotiations. Solidarity had to demobilise its most radical members whereas the communist establishment had to keep in check its members most ardently opposed to the loss of its monopoly of political power.

While both sides sought to find ways to set in motion a gradual transition to liberal democracy that would bring about social stability, they differed as to the measures to be taken, their timing and the overall length of the transition process. There was consensus that change was to be incremental rather than radical as the loss of control by either the communist establishment or Solidarity could trigger social unrest. To retain public support, Solidarity aimed to extract concessions involving political rights such as freedom of speech and association, liberalisation of censorship, and acceptance of partly free elections that would guarantee Solidarity a place in parliamentary politics. The communist establishment wanted to keep control of the government and guarantee for itself and its allies a constitutional majority in the Parliament.

The result was a pact: the round table agreements, which not only set out a framework for an orderly and gradual transition to liberal democracy controlled by the communist establishment, it also made a critical constitutional choice of the type of government and electoral system. It established a semi-presidential system of government with electoral law based on single-member electoral districts each allotted to a different party. The choice was not the product of grand debate as to which of many possible systems of government and electoral arrangements would best ensure that the 'public voice' was heard and politicians were held accountable - variables critical for the quality of democracy. The political expediency of assuring the communist establishment's political control of the transition during a five-year period was the major consideration determining this critical constitutional choice. For the communist establishment, two safety measures had to be inserted into the agreements to accomplish this 
goal. The first was the electoral arrangement that provided for only 35 per cent of the parliamentary seats to be freely elected, with the remaining 65 per cent allocated to communists and their various allies. ${ }^{18}$ Elections were scheduled for 4 June 1989- less than two months after the round table agreements were signed. This short lead-time was supposed to prevent Solidarity from launching an effective electoral campaign.

The other safety measure had two components. First, the 1952 Constitution was amended to extend the powers of the President over national defence, internal affairs and foreign policy, with the office implicitly reserved for the first fiveyear term for a nominee of the communist establishment to be endorsed by a new bicameral National Assembly consisting of the Sejm (the lower house of Parliament) and the Senate. ${ }^{19}$ The office of President was effectively reserved for the communist establishment strongman, General Wojciech Jaruzelski. Second, as an extra precaution, the presidential term was set for six years so that the communist establishment could retain some additional control in case the first genuinely free elections - to be held in one year-triggered social unrest, endangering members of the communist establishment. ${ }^{20}$

These safety measures failed to guarantee the 'desired' outcome for the communist establishment, as it suffered a disastrous electoral defeat on 4 June 1989. The scope of the defeat was enormous, changing completely the political landscape and the calculations of all political actors involved. Despite a very short electoral campaign, the network of Civic Committees - sparked by the establishment of the 'Civic Committee to Lech Wałęsa' and organised around the then legally existing Clubs of Catholic Intelligentsia and the underground Solidarity chapters - launched an impressive campaign that brought the stunning electoral victory. ${ }^{21}$ Following the elections, the communist establishment's allied parties - the parties that in the People's Poland were completely subordinated to the communist establishment, although not formally part of it - were ready to switch sides, thus undermining the 65 per cent electoral safeguard. Eventually, this facilitated the formation of a coalition government with the post of prime minister to be held by Solidarity. As a result, a government led by a noncommunist emerged in Central Europe for the first time since the imposition of communism in the aftermath of World War II. As this was achieved by peaceful means, a path was cleared for other communist countries to follow.

\footnotetext{
18 The provision assigning guaranteed seats to the communist establishment was not to apply in the following elections to be held four years later.

19 The President has also obtained the power to veto acts of the Sejm with two-thirds of votes, to overhaul the presidential veto and to dissolve Parliament if it takes steps undermining the President's discretion over national defence and observing existing military alliances. Wojciech Jaruzelski, leader of the communist establishment, was elected by the National Assembly by one vote.

20 Kamiński (1992).

21 Słodkowska (2001).
} 
Further, political developments in Poland also demonstrated that self-imposed constraints intended to mitigate the risks of external and internal intervention lost their relevance, as there was neither a Soviet intervention nor a domestic backlash from hardline communists and their apparatus of repression. And, following the collapse of the Communist Party, a completely new political situation emerged, making the round table agreements completely out of sync with societal aspirations and freedoms enjoyed in countries that got rid of communist rule after Poland. There was growing political momentum in favour of scrapping the anachronistic 'pact' and accelerating political change. Society demonstrated a surprising degree of self-organising capacity during and after the electoral campaign, threatening the negotiated pact.

With the disappearance of the Communist Party, however, the cohesion of Solidarity also disappeared. The so-called 'war at the top' pitched Prime Minister, Tadeusz Mazowiecki, and several other Solidarity participants in the round table negotiations against Lech Wałęsa, who was highly critical of Mazowiecki's commitment to stick to the letter and spirit of the 'pact'. Although Wałęsa eventually prevailed, this not only marked the end of Solidarity as a national movement, it also deflated pressures for institutional change in society at large. As Ekiert and Kubik show, ${ }^{22}$ an informal agreement among forces of the new pro-democratic establishment, including reformist former communist establishment members, and some former Solidarity leaders, emerged with an explicit goal to demobilise society.

Whether there actually was such an agreement is not critical. The delays in holding genuinely free elections and prevarications about the choice of electoral system have effectively suppressed the political momentum and energy released by the 1989 election. Although free elections were held in September 1991two years earlier than envisaged by the round table agreements - this was more than a year after such elections were held in most other ex-Soviet Bloc countries. Political participation was further weakened by tinkering with the electoral system. ${ }^{23}$ The proportional representation (PR) system that was adopted had no threshold and the Hare-Niemeyer method of transferring votes into mandates favoured small parties. Twenty-eight parties won seats in the Sejm and eight formed the governing coalition. Both the delay and the PR system saved the former Communist Party from total political annihilation. Paradoxically, while the idea of adopting PR came out of the already deeply divided post-Solidarity camp, it was eagerly supported by the reformed communist establishment. ${ }^{24}$ 
While one can ponder endlessly over the underlying political calculations of the various political factions involved in making this critical constitutional decision, the bottom line is that short-term political expediency prevailed over the more ambitious task of building long-term institutional foundations for a competitive and transparent political system. Entrenched interests derailed any political debate on broader constitutional issues. The loss of the constitutional momentum was bitterly noted by Zakrzewska, a respected constitutional lawyer who participated as an expert in the parliamentary deliberations on the new constitutional order. ${ }^{25}$ Among foreign observers, Ackermann and Dahrendorf made similar observations, with the latter explaining to 'his Polish friend'to borrow a subtitle of his book - the importance of designing constitutional arrangements and strengthening civil society. ${ }^{26}$

The long-term impact of these poorly designed political institutions has been increasingly apparent in the lack of cooperation between political parties and their inability to compromise and reach agreements. Having examined parliamentary politics in Poland in the 1990s, Kamiński ${ }^{27}$ concludes that political instability, social inefficiencies and economic underperformance during this period can be attributed to the institutional vacuum resulting from the lack of cooperation among political actors. It is likely that had Solidarity leaders spent more time debating institutional design and the Constitution during the initial stages of transition, instead of attacking each other and jockeying for position, the quality of democracy would have been vastly improved. Instead, the constitutional moment for liberal revolution - to borrow an apt phrase from Ackerman $^{28}$ - or a window of opportunity was missed. ${ }^{29}$ Ackerman also notes that the choice of the type of government and organisation of the state rather than the transfer of property rights to the private sector should have been the priority. But continuing institutional reform has not been the priority for any post-communist government.

\section{Concluding Observation}

Some two decades after the demise of communism, Poland lags behind other members of the Luxemburg group in the quality of democracy. Had Poland not been best endowed to handle transition on the eve of the collapse of communism and paved the way for dismantling communism in other Soviet Bloc countries,

25 Zakrzewska (1993).

26 Ackermann (1992) and Dahrendorf (1990).

27 Kamiński (2003).

28 Ackerman (1992).

29 It is worth noting that it was not missed as far as economic reforms were concerned. Balcerowicz (1994) has also referred to this moment as the 'honeymoon' or 'period of extraordinary politics'. 
this state of affairs would not have been of interest. The developments in 1980-89 led to the emergence of a well-developed civil society with selforganising capacities that were tested on many occasions, including during the hastily organised elections in June 1989. Ironically, Poland had already lost its leading position in political transformation in 1990 when most other former Soviet satellites freely elected their post-communist governments, while Poland persisted with its 'pacted' arrangements and with the former First Secretary of the Communist Party - responsible for the imposition of martial law in 1981 — as its president.

Subsequent developments have demonstrated that the huge civil society embodied in Solidarity - which had no equivalent in any other post-communist country - was also a source of weakness. The disappearance of external and internal threats that bonded Solidarity together led to its fragmentation and fratricidal struggles. As a result, a much more important issue of establishing the constitutional underpinnings for a democratic society and state has been crowded out by politicking narrow interest groups. The 'pacted' transition with built-in safeguards for the communist establishment thus erected barriers to the emergence of high-quality political institutions. But its legacy - the mixed presidential-parliamentary system of government - is not wholly responsible for subsequent poor political performance. The struggle for power within the increasingly fragmented Solidarity appears to have also been responsible for disappointing political performance.

Polish economic transformation, however, which symptomatically was not a part of the round table agreements and for which gradualism as an approach to first-generation reforms was rejected, was initially not adversely affected by Poland's poor political performance. The country quickly embarked on the path of sustainable long-term economic growth while economic institutions and policies introduced under the Balcerowicz transformation-cum-stabilisation program have been sufficiently resilient to cope with the ill-designed political system, albeit with an important qualification. The deterioration in the values of the QoD index in 2000-06, however, coincided with sub-par economic growth performance relative to other new 2004 EU member states except for Hungary. Although Poland's performance was exceptionally good in 2008, it has to be assessed against relatively modest growth gains in the years preceding the current economic bust and marked improvement in the QoD index. Perhaps it should be seen as an illustration of the 'disadvantage of an early lead' as well as evidence that bold reforms bring fruits later, rather than earlier.

Note: The authors are grateful to Marek Kamiński, Stefan Markowski and two anonymous referees for their comments on earlier versions of this paper. The usual caveats apply. 


\section{Bibliography}

Ackerman, B. 1992. The Future of Liberal Revolution, Yale University Press, New Haven, Conn.

Ash, T. G. 2009. '1989', New York Review of Books, vol. 56, no. 17 (5 November).

Balcerowicz, L. 1994. 'Understanding post-communist transitions', Journal of Democracy, vol. 5, no. 4 .

Bunce, V. 2003. 'Rethinking recent democratization: lessons from the postcommunist experience', World Politics, vol. 55, no. 2.

Dahrendorf, R. 1990. Reflections on Revolutions in Europe, Times Books, London.

Ekiert, G. and Kubik, J. 1999. Rebellious Civil Society. Popular protest and democratic consolidation in Poland, 1989-1993, The University of Michigan Press, Ann Arbor.

Geremek, B. and Żakowski, J. 1990. Rok 1989: Geremek opowiada, Żakowski pyta [1989: Geremek talks, Żakowski asks], Plejada, Warsaw.

Hellman, J. 1998. 'Winners take all: the politics of partial reform in postcommunist transition', World Politics, vol. 50, no. 2, pp. 203-34.

Kamiński, A. Z. 1992. An Institutional Theory of Communist Regimes: Design, function, and breakdown, ICS Press, San Francisco.

Kamiński, A. Z. and Kamiński, B. 2001. 'Governance in transition: the challenge of subverting corruption', in Economic Survey of Europe. Number 2, United Nations, New York and Geneva.

Kamiński, A. Z. and Kamiński, B. 2009. Trajectories of transition from communism: bumps, exits and deviations, Paper presented at Twenty Years After Conference, University of California, Irvine, 5-8 November, <http:// www.democ.uci.edu/research/conferences/documents/kaminski-kaminski. $\operatorname{pdf}>$

Kamiński, A. Z. and Kurczewska, J. 1994. 'Institutional transformations in Poland: the rise of nomadic political elites', in M. Allestalo et al. (eds), The Transformation of Europe, IFiS Publishers, Warszawa.

Kamiński, B. 1992. 'Systemic underpinnings of the transition in Poland: the shadow of the roundtable agreements', in C. Saunders (ed.), Economics and Politics of Transition, Macmillan, London. 
Kamiński, M. 2002. 'Do parties benefit from electoral manipulation? Electoral laws and heresthetics in Poland', Journal of Theoretical Politics, vol. 14, no. 3, pp. 325-59.

Kamiński, M. 2003. The collective action problems of political consolidation: evidence from Poland, Paper 03-03, Center for the Study of Democracy, University of California, Irvine.

Kamiński, M., Lissowski, G. and Świstak, P. 1998. 'The "revival of communism" or the effect of institutions? The 1993 Polish parliamentary elections', Public Choice, vol. 97, pp. 429-49.

Kaufmann, D., Kraay, A. and Mastruzzi, M. 2009, Governance Matters VIII: Governance indicators for 1996-2008, The World Bank, Washington, DC, <http://www.worldbank.org/wbi/governance>

Laydeyret, G. 1991. 'The problem with PR', Journal of Democracy, Summer.

Lijphart, A. 1994. Electoral Systems and Party Systems: A study of twenty-seven democracies, 1945-1990, Oxford University Press, Oxford and New York.

Linz, J. and Stepan, A. 1996. Problems of Democratic Transition and Consolidation: Southern Europe, South America, and post-communist Europe, The Johns Hopkins University Press, Baltimore and London.

McFaul, M. 2002. 'The fourth wave of democracy and dictatorship: noncooperative transitions in the post-communist world', World Politics, vol. 52 , no. 2 .

Mainwearing, S. 1992. 'Presidentialism in Latin America', in A. Lijphart (ed.), Parliamentary versus Presidential Government, Oxford University Press, Oxford and New York.

Norris, P. 1997. 'Choosing electoral systems: proportional, majoritarian and mixed systems', International Political Science Review, vol. 18, no. 3.

O'Donnell, G. and Schmitter, P. C. 1986. Transitions from Authoritarian Rule: Tentative conclusions about uncertain democracies, The Johns Hopkins University Press, Baltimore.

Quade, Q. L. 1991. 'PR and democratic statecraft', Journal of Democracy, Summer.

Sala-I-Martin, X., Blanke, J., Drzeniek Hanouz, M., Geiger, T., Mia, I. and Paula, F. 2009. 'Chapter 1.1', in Global Competitiveness Report, 2008-09, The World Economic Forum, Geneva. 
Humanities Research Vol XVI. No 3. 2010

Sartori, G. 1994. Comparative Constitutional Engineering: An inquiry into structures, incentives, and outcomes, New York University Press, New York.

Słodkowska, I. (ed.) 2001. Wybory 1991: Programy partii i ugrupowań politycznych [Elections 1991: Programs of political parties and organizations], ISP PAN, Warszawa.

Stokes, G. 1993. The Walls Came Tumbling Down: The collapse of communism in Eastern Europe, Oxford University Press, New York and Oxford.

Yesilada, B. A. and Wood, D. M. 2010. The Emerging European Union, Longman, New York.

Zakrzewska, J. 1993. Spór o konstytucje [The Dispute about Constitution], Wydawnictwo Sejmowe, Warszawa. 